\title{
Subsidy Interventions; Implementation Challenges and Successes in Secondary Schools. A Case of Selected Counties in Kenya.
}

\author{
Zachariah K. Kosgei (Ph.D) ${ }^{1}$, *Joyce J. Kurgat ${ }^{1,2}$, Keter K. Joshua ${ }^{2}$, Kisilu \\ Kitainge (Ph.D) ${ }^{2}$. \\ ${ }^{1}$ Moi University, School of Education. \\ ${ }^{2}$ University of Eldoret, School of Education.
}

\begin{abstract}
The purpose of this study is to assess the impact of government subsidy on the key determinants of educational attainment and the challenges in their implementation. The specific objectives of the study are; to find out the effect of subsidy on school buildings and infrastructure, to determine the influence of FDSE on enrolment and performance in KCSE and to determine the challenges facing the implementation of FDSE. The study adopted a mixed method design. The target population included education officials and principals of high schools. The respondents were selected using purposive, and simple random sampling technique and the instruments for data collection were questionnaire and interview schedule. Data was analyzed using descriptive statistics and inferential statistics. The study findings revealed that irrespective of the geographical location of schools, subsidies have a positive and significant effect on the indicators of educational attainments. The study therefore amplifies the need for the government to streamline the public subsidization policy in view of expectations of sessional paper no 1 of 2005, vision 2030, and the global imperatives namely MDGs and EFA goals.
\end{abstract}

\section{Introduction}

The Kenya government has since independence recognized the role of education as a cornerstone of socio-economic development and a means of improving the welfare of individuals and the society at large (Ayot and Briggs, 1988). Studies by World Bank (1980) and Psacharapoulos and Woodhall (1985) established that investment in education guaranteed higher individual returns than investment in alternative sectors of the economy. Maryor et al (2005) and IBED, (2005) noted that education is viewed as the root source of Human, Social, Cultural, and Economic capital and is perceived as legitimate in terms of both individual and collective good, resulting into explosive growth both in National and Global arena. KIPPRA (2008) observed that provision of quality education is important in generating the opportunities and benefits of social and economic development.

Secondary Education has been perceived as a critical level in the overall development of a county (Psachapoulos and Woodhall, 1985; Wood and Mayer, 1999; Appleton, 2001 and Mingat, 2004). According to EPAA (2007) and World Bank (2008) financing secondary education is important as it constitutes an investment in education that yields considerable social and private returns. UNESCO (2008) observed that in Africa, there are four critical reasons for investing in secondary education. First secondary education is critical for economic growth and development (UNESCO, 2002; Lewin and Stuart, 2003). This is due to the fact that the secondary level provides countries with the human capital needed for economic growth. In addition it provides a link between primary education and further learning and training (Knight and Sabot, 1990). Secondly secondary education contributes to the socialization process of young people, among them youth, who are at risk of losing the social and moral values (UNESCO, 2004). Secondary School age-group (Adolescence) has the greatest potential for changing its behaviors as secondary education can be decisive in enhancing positive social values among the youth (Lewin,2006). Thirdly, secondary education provides returns and offers young people the opportunity to acquire human capital unlikely to be developed in the lower grades (Knight and Sabot, 1990). This in turn enables the youth to develop job- oriented skills, participate fully in the society, take control of their own lives and continue learning (G.O.K, 1999). Finally the demand for secondary education is increasing rapidly (Bregman and Tallmeiser, 2002; IBRD, 2005)

According to Lewin and Stuart (2003), investment in secondary education in sub-Saharan Africa will provide countries with critical higher-level skills and knowledge for advanced learning and training of technicians, scientists, entrepreneurs and yields considerable social and private returns. Secondary education plays a crucial role in preparing for higher education and for work, for youth and in a life-long learning perspective (World Bank, 2007). In Sub-Saharan Africa, less than one third of the age-group takes part in secondary education. In these countries, there is a strong pressure to expand secondary level in the education 
system through direct government interventions in the financing of education (EPAA, 2007; UNESCO, 2008; World Bank, 2007).

The rationale for subsidizing secondary education in Kenya, has its basis in the development of primary education. Most third world countries appreciate the fact that the strength of secondary education is the primary education. Consequently most third world countries, Kenya included have subsidized primary education with the long term goal for developing secondary education. In this regard, as early as 1964, the government established the Ominde Commission to chart the course of the development of the sector. The Commission emphasized Kenya's need for universal primary education (KIPPRA, 2008). Partial implementation of this recommendation started in 1974 and covered standards 1-4; it was extended to standards 5-7 in 1978. The initiative resulted in massive enrollments in primary schools; the gross enrollment rate (GER) level increased from 50 percent in 1963 to a peak of 105.4 percent in 1989. However, the high enrollments were negatively affected by the cost sharing policy. The policy hindered many children, especially those from economically marginalized groups, from accessing primary education (GOK, 2005). Education therefore became the preserve of the well-to-do members of Kenyan society. By December 2002, GER had fallen to 88.2 percent, compared with the 1989 level of 105 percent. Declining enrolment heightened concern among leaders; thus, the provision of free education became the main agenda during the general election of December 2002 (UNESCO, 2008).

Public subsidization of education all over the world is motivated by the governments desire to address the social problems of access, equity and poverty (World Bank, 2002). Several studies done both in the developed and developing countries all point out to the fact that a subsidy influences, among other educational indices equity and enrolment (Rono, 2005).

\section{Objectives}

1. To find out the effect of subsidy on school buildings and infrastructure.

2. To determine the influence of FDSE on enrolment and performance in KCSE.

3. To determine the challenges facing the implementation of FDSE.

\section{Methodology}

The research philosophy subscribed to is pragmatism worldview. Pragmatism derives from the work of Peirce, James, Mead, and Dewey (Cherryholmes, 1992). The pragmatist researchers look to the what and how to research, based on the intended consequences where they want to go with it. Pragmatists agree that research always occurs in social, historical, political, and other contexts. This study adopted a mixed methods design for it is useful in helping researchers meet the criteria for evaluating the "goodness" of their answers ( Tashakkori and Teddlie, 1998) better than do the single approach designs. The target population for this study comprised senior ministry of education and ministry of planning officials, the provincial director of education the district education officers and the school principals of secondary schools in North-rift. Questionnaire and interviews were the instruments used to collect data. The questionnaire was both structured and semi-structured.

\section{Specific Subsidies Received in the Secondary Schools}

\section{Findings}

It is noted that all the sampled schools benefited from Free Secondary Education subsidy. Constituency Development Fund (CDF) came next with the Constituency Bursary Fund (CBF) being the third.

\section{School Buildings and Infrastructure before the Introduction of FDSE}

The school situation in terms of buildings and infrastructure before the introduction of the FDSE subsidy in 2008 was assessed. It is observed that the majority of the school principals either disagreed or strongly disagreed that the school situation before 2008 was worse than 2011 and 2012, the period after the introduction of FDSE. This implies that the subsidy has had a positive effect on the school infrastructure.

On the status of classrooms before 2008, majority of the respondents in the ASAL: Turkana county, contrary to the other counties, strongly agreed that before the introduction of FDSE in 2008, there were adequate number of classrooms than 2011 and 2012. This position contrast with that of Elgeiyo-Marakwet where majority strongly disagreed. This implies that the effect of FDSE on number of classrooms as far as status of classrooms is concerned is not uniform across the counties.

On the status of toilets before the introduction of FDSE, majority of the respondents in Turkana county strongly agreed that before the introduction of FDSE, there were adequate number of toilets than 2011 and 2012. This contrasts with the findings in Elgeyo Marakwet where majority disagreed to the statement that before the introduction of FDSE there were adequate number of toilets than 2011 and 2012. These contrasting results indicate the impact of FDSE on toilets varied from county to county. 
The effect of FDSE on sanitation facilities was also investigated. It is observed that whereas in Turkana county which has been described as purely ASAL county, majority of the respondents strongly agreed that there was adequate number of sanitation facilities in the county before the introduction of FDSE, implying that FDSE has worsened the status of sanitation facilities. This contrasts with the findings in all the other counties implying that the FDSE has positively impacted on sanitation facilities while in the ASAL county of Turkana, the effect is negative.

On the adequacy of teachers' furniture, majority of the respondents in Nandi, Uasin-Gishu and WestPokot counties disagreed to the statement that before the introduction of FDSE, teachers' furniture was adequate. In Turkana county, majority (44.4\%) strongly agreed that the teachers' furniture was adequate. A similar picture is painted on the status of desks and chairs and the adequacy of the number of buildings in schools.

\section{The Support Schools Received Prior to FDSE and After}

Majority of the respondents in the six counties disagreed to the statement that before FDSE was introduced their schools had not received any support from the government or any other agency. This implies that these schools use to get support even before the introduction of FDSE. By virtue of these schools being public, they enjoy public and other stakeholder support. Majority of the respondents strongly agreed that FDSE led to increase in school resources and improved school supplies. Many organizations supported the government after FDSE. This implies that the government's initiative of introducing FDSE enjoys the goodwill of the other stakeholders in the provision of education.

On whether FDSE had led to increase in school resources, the responses were also varied. The respondents were however unanimous that school supplies were improved by FDSE. Majority of the respondents in all the counties either strongly agreed or agreed, implying that FDSE has had a positive impact on school supplies in all the counties, irrespective of whether they are ASAL or non-ASAL.

Based on the above findings, the researcher carried out a paired samples $t$ test to test the null hypothesis that states that, "there is no statistically significant relationship between educational attainment and provision of public subsidies." It is observed that; $\mathrm{t}(267)=-10.065, \mathrm{p}=.000$

This was found to be significant at 0.05 level, implying that the null hypothesis is rejected. It is concluded that there is a statistically significant relationship between the county of respondent and the adequacy of desks and chairs before the introduction of FDSE. Some counties were worse off than others as far as the adequacy of desks and chairs is concerned before FDSE was introduced.

\section{Effects of FDSE on Enrolment and Students' Performance in KCSE}

The researcher investigated the effect of FDSE subsidy on enrolment and student performance in KCSE according to the views of the principals. Figure 4.1(a) and (b) presents the effects of FDSE on the two variables.

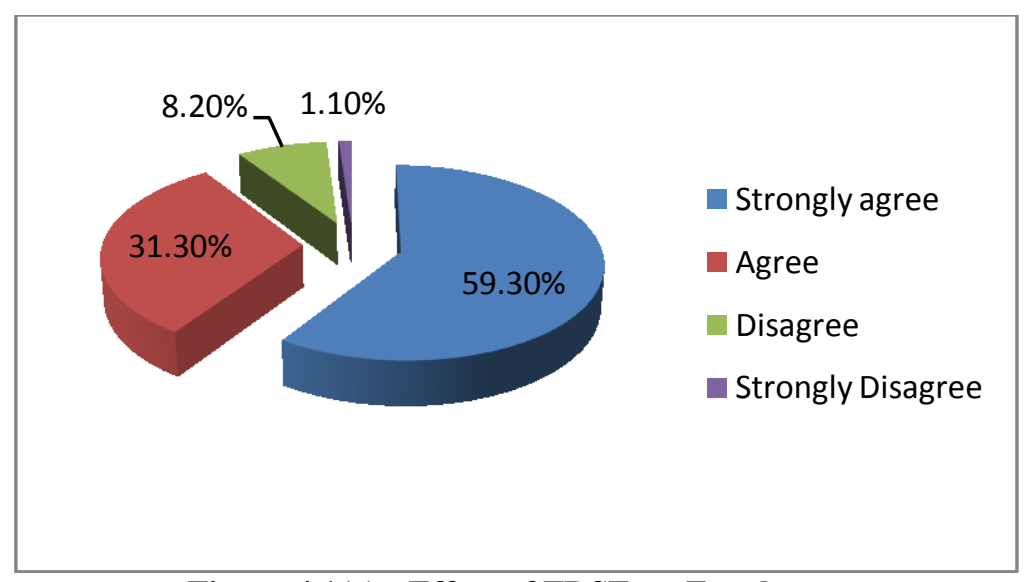

Figure 4.1(a): Effect of FDSE on Enrolment 


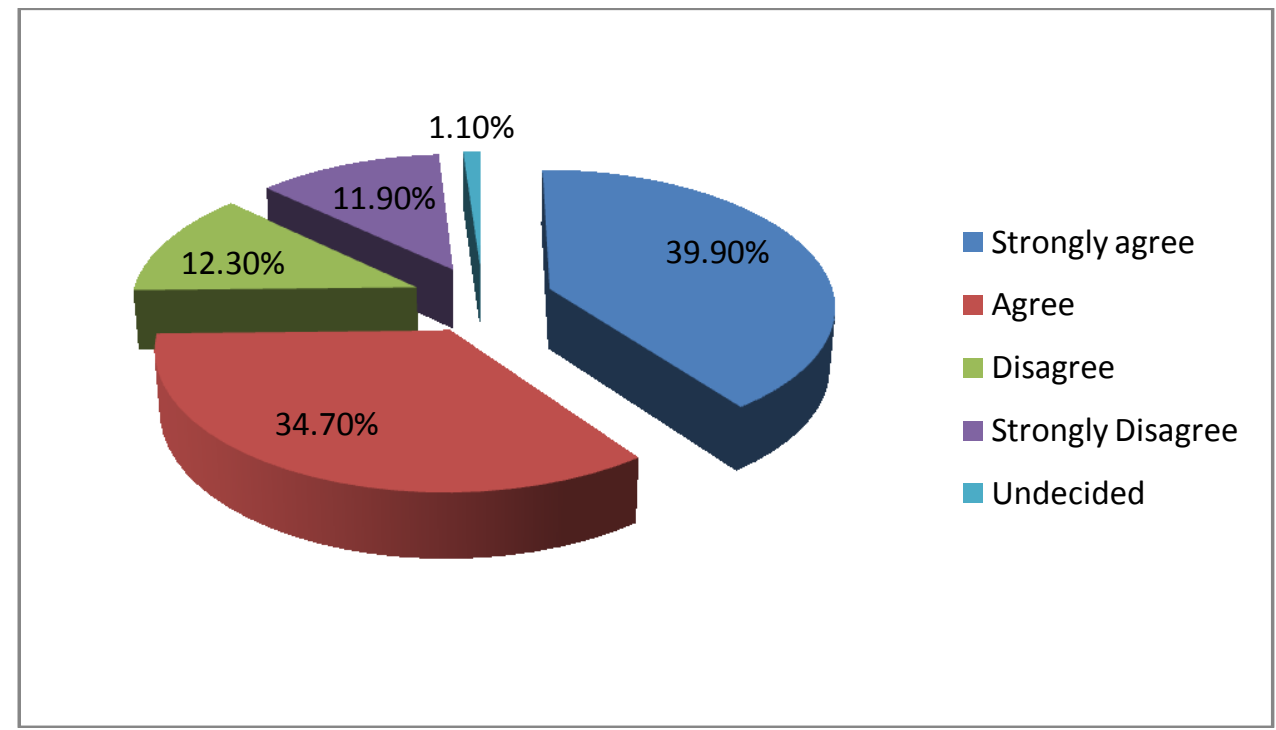

Figure 4.1(b): Effect of FDSE on Student Performance

Figure 4.1 (a) presents data on the views of principals on whether the support raised student enrolment. It is observed that majority of the respondents strongly agreed that the subsidy raised student enrolment. These findings agree with those of Frederikson (1997) in Sweden and Dunarski (1994) in Canada that found a robust positive relationship between public subsidy and enrollment and student retention.

Majority of the respondents strongly agreed that the support improved KCSE performance. These findings are in agreement with those of World Bank, (2008) in Zambia, UNESCO, (2005) in Cameroon and UNICEF (2008) in Francophone countries. All these studies found a positive and significant relationship between public subsidy and enrolment. Another $39.9 \%$ and $34.4 \%$ strongly agreed and agreed respectively, that the FDSE support improved KCSE performance. These findings are in line with those of KIPPRA (2008) that revealed that government subsidy on education has a positive relationship with performance in the national examinations. Subsidy has positively influenced enrolment and KCSE performance. These findings are in sharp contrast with those of Card (2000) in USA that found a negative relationship between public subsidy and enrolment and student performance.

\section{Effect of FDSE on Learning Achievement}

Figure 4.2 present data collected on the effect of FDSE on learning achievement.

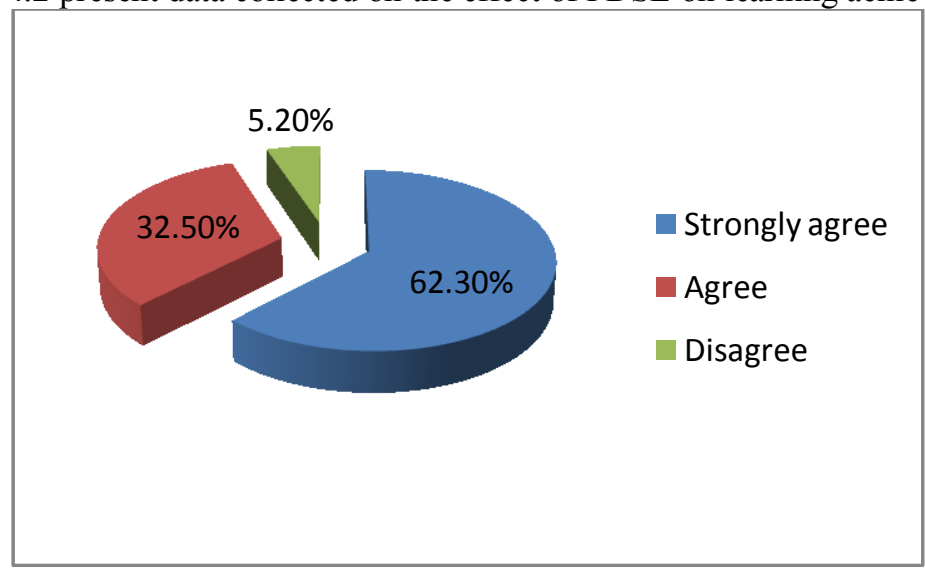

Figure 4.2: FDSE has positive effect on learning achievement

Majority of the respondents strongly agreed that FDSE subsidy has a positive effect on learning achievement. These findings are in agreement with those of UNICEF (2008), Lewin (2008), UNESCO, (2005) and World Bank, (2008). All these studies found a robust significant relationship between public subsidy and learning achievement. In fact Lewin (2008) in his study in sub-Sahara Africa went ahead to recommend that governments in sub-Sahara Africa should increase their budgetary allocations to education with a view to raising the quality of education and learning achievements. 
In the light of the above findings on the influence of the government subsidy on enrolment, KCSE performance and the overall learning achievement, an analysis of variance (ANOVA) was carried out to test the hypothesis that stated that "there is no statistically significant relationship between the inputs and outcomes of educational attainment".

The outcomes of educational attainment (enrollment, KCSE performance and learning achievement) are the dependent variables while FDSE support is the independent variable. On the relationship between the enrolment index and the support it is observed that; $F(4,263)=3.863 ; \mathrm{p}<0.05$

This was found to be significant and hence the null hypothesis that stated that there is no significant difference between the inputs and outcomes of educational attainment was rejected. Consequently it was concluded that there is a statistically significant relationship between enrolment as an outcome of educational attainment and the input. These findings concur with those of World Bank (2002) which found out a statistically significant relationship between public subsidy to education and enrolment. On the relationship between the FDSE support and performance in KCSE, it was found as; F (4,263) $=44.025 ; \mathrm{p}<0.05$. This was also found to be significant at 0.05 level and hence the researcher rejected the null hypothesis that stated that "there is no significant difference between the FDSE support and performance" and concluded that there is in fact a significant difference between the support and performance. This conclusion is in sharp contrast with the findings of Card (2000) who found an insignificant relationship between the FDSE support and performance.

ANOVA results on the relationship between the FDSE support (input) and learning achievement (outcome). It was observed that; $F(4,263)=19.213 ; p<0.05$. This was found to be significant at 0.05 level. The null hypothesis that stated that "there is no statistically significant difference between the FDSE support and learning achievement" was rejected. It was therefore concluded that there is a statistically significant difference between the FDSE support and learning achievement.

On the relationship between FDSE support and overall school resources, it was found that; F $(4,263)=$ 18.623; $\mathrm{P}<0.05$. This was significant and therefore the null hypothesis that stated "there is no statistically significant difference between the inputs and school resources" was rejected at 0.05 level. It was concluded that there is a significant relationship between the two variables. This conclusion is supported by Lewin (2008) in the study in Sub-Sahara Africa that found a significant relationship between government subsidy and the resource mobilization abilities of schools.

\section{Staff Development Activities Following the Introduction of FDSE.}

Since FDSE project was a new initiative, investigation on the staff development activities that were developed for successful implementation of FDSE was carried out. This is anchored on the fact that capacity building initiatives greatly determines successful implementation of any project.

Majority of the respondents interviewed either strongly agreed or agreed that a number of training programmes were mounted following the introduction of FDSE subsidy. Majority of the respondents agreed that KESI developed a training programme and also that there are a number of staff development and teacher training activities that were undertaken between 2008 and 2010. These staff development activities focused more on teacher and teaching resources. The government developed teacher-tailored training programmes to support implementation of FDSE. The training programmes developed focused more on quality education. In overall, majority of the respondents acknowledge the fact that there are quite a number of training programmes that were developed to aid implementation of FDSE subsidy. This implies that the inherent successes in the implementation of FDSE subsidy is hinged on the number of tailor-made training programmes that were developed following the introduction of FDSE whose major focus was quality education.

\section{Implementation Challenges Facing FDSE Subsidy}

Both the principals and senior ministry officials acknowledge that the greatest challenge facing FDSE is the delayed disbursement of funds that negatively impacts on the effectiveness of the subsidy to intervene. FDSE subsidy intervention therefore may not be adequately realized because of the delay. They also admit that limited funds is a major challenge. The allocation to schools is so limited that the interventional impact may not be felt in schools. Ineffective PTA and/or B.O.G have also been cited as another implementation challenge. B.O.Gs/PTAs in some schools are inactive/non-functional or where they are functional, their energy is more of destructive than constructive. Majority of the principals also cited the challenge of unclear policy guideline that in some cases derail the successful implementation of the FDSE subsidy

All the senior ministry officials cited poor accountability of funds that precipitates corruption, weak legal framework, diversity in school requirements, rising poverty level, inflation and the demands of ASAL schools as major challenges in the implementation of FDSE subsidy. 
The analysis of data revealed that the specific public subsidy interventions included those touching on school infrastructure and processes and the implementation challenges include: logistical, technical, political and financial related challenges.

\section{Conclusion}

Based on the findings, there is a relationship between educational attainment and provision of public subsidy. This implies that any change in the provision of public subsidy would have a definite effect on educational attainment.

There is a relationship between public subsidy interventions on classrooms, toilets, sanitation facilities, teachers' furniture, desks and chairs and number of school buildings in all the five counties except the ASAL Turkana county where the subsidy seem to have had less influence on the intervention targets. However, in all the six counties, the subsidy positively influenced enrolment, KCSE performance, school supplies and learning achievement.

\section{References}

[1]. Appleton, S. (2001). "What Can We Expect of Universal Primary Education?" In Uganda's Recovery: The Role of Firms, Farms and Government, ed. R. Reinikka and P. Collier. Washington, DC: World Bank.

[2]. Ayot, H. O. \&Briggs, H. (1988) Economics of Education. Nairobi: Kijabe Printing Press.

[3]. Bregman, J., \& Stallmeister, S. (2002). Secondary education in Africa: Strategies for renewal. Africa Region Human Development Working Paper Series. Washington, DC: Human Development Sector Africa Region, The World Bank.

[4]. Card D.A, \& Payne A. A. (2002). School finance reform, the distribution of school spending, and the distribution of student test scores. Journal of Public Economics 83

[5]. Dynarsky,M. (2003). Loans, Liquidity and Schooling decisions. Harvard University, Kennedy school of Government. NBER

[6]. Frederickson, H.\& George.S (1997). The Spirit of Public Administration. San Francisco, California: Jossey Bass.

[7]. Government of Kenya (1999) Totally Integrated Quality Education; Government Printer; Nairobi.

[8]. Government of Kenya (2005). Sessional Paper No. 1 of 2005 on A Policy Framework for Education, Training and Research. Nairobi: Government Printer.

[9]. KIPPRA (2008). Public Expenditure Tracking of Secondary Education Bursary Fund in Nairobi Province, Kenya at http://www.ipar.or.ke

[10]. Knight, J.B.; \& Sabot, R.H. (1990). Education, productivity and inequality: The East African natural experiment. Oxford: Oxford University Press.

[11]. Lewin K. M (2006). Planning for Secondary Expansion in Sub Saharan Africa - Key Issues for Sustainable Growth in Access Perspectives in Education, Vol 24(2), June 2006.

[12]. Lewin K M (2008). Strategies for Sustainable Financing of Secondary Education in Sub-Saharan Africa. Africa Human Development Series. Working Paper No 136. World Bank, Washington

[13]. Lewin, K. M., \& J. S. Stuart. (2003). Researching Teacher Education: New Perspectives on Practice, Performance and Policy. Research Series Monograph, U.K. Department for International Development, London.

[14]. Mingat, A., R. \& Rakotomalala, J-P. Tan (2004) 'Financing education for all by 2015: simulations for 33 African countries' Washington DC: World Bank

[15]. Psacharapoulos, G. \& Woodhall, M. (1985). Education for Development; An Analysis of Investment Choices, Washington D. C. World Bank.

[16]. Rono, P. K. (1991). Cost-Sharing in Kenya. BER KU Nairobi. Sector Review 2006

[17]. Tashakkori, A., \& Teddlie, C. (1998). Mixed-methodology: Combining qualitative and quantitative approaches. Thousand Oaks, CA: Sage Publications.

[18]. UNESCO (2002). 'Education for all. An international strategy to operationalise the Dakar Framework for Action on education for all (EFA)'. April 2002. Paris: UNESCO

[19]. UNESCO (2005). EFA Global Monitoring Report. UNESCO; Paris.

[20]. UNESCO (2006). Global education digest: Comparing education statistics across the world. Montreal: UNESCO Institute for Statistics.

[21]. UNESCO (2010). EFA Global Monitoring Report 2010. Reaching the marginalized. Paris; OUP.

[22]. UNESCO. (2004). Global monitoring report, 2005. Education for All. The quality imperative. Paris: UNESCO.

[23]. Wood, A., \& J. Mayer. (1999). “Africa's Export Structure in a Comparative perspective." Institute of Development Studies. University of Sussex, United Kingdom.

[24]. World Bank (2002) Education and HIV/AIDS: A Window of Hope World Bank, Washington DC

[25]. World Bank (2003). Lifelong Learning in the Global knowledge Economy: Challenges for Developing Countries. Washington D.C.: World Bank

[26]. World Bank (2005). Expanding Opportunities and Building Competencies for Young People: A New Agenda for Secondary Education. Washington, DC: World Bank.

[27]. World Bank (2008). World Development Indicators 2008-09. Washington DC. World Bank

[28]. World Bank. (1999). Priorities and Strategies for Education. The WorldBank. Washington D.C.

[29]. World Bank. (2002). Constructing Knowledge Societies: New Challenges for Tertiary institutions. Washington D.C. world Bank 